\title{
Penerapan Pendekatan Pembelajaran SAVI terhadap Kemampuan Berpikir Kritis Siswa pada Materi IPS di Kelas V SD
}

\author{
Qonitah Kurnianingsih \\ Universitas Sultan Ageng Tirtayasa - Serang, Banten \\ qonitahkurnia@gmail.com \\ Ana Nurhasanah \\ Universitas Sultan Ageng Tirtayasa - Serang, Banten \\ ananur74@yahoo.co.id \\ Zerri Rahman Hakim \\ Universitas Sultan Ageng Tirtayasa - Serang, Banten \\ zerrirahmanhakim@gmail.com
}

\begin{abstract}
The purpose of this research is to know and analyze the application of SAVI (Somatic, Auditory, Visual, Intellectual) learning approach to student's critical thinking skills on social science subjects in elementary school. This research used quasi experiment method with Nonequivalent Control Group Design. Sampling technique of the research used purposive sampling technique. The sample chosen was VA students as the experimental class that received treatment SAVI learning approach and $V B$ students as the control class that received conventional learning. Based on the result of differences two averages posttest hypothesis test showed $-2,01<2,67>2,01\left(-t_{\text {table }}<t_{\text {test }}>t_{\text {table }}\right)$, then $H_{0}$ is refused and $H_{a}$ is accepted. It shows that there are differences of critical thinking skills between students who received SAVI learning approach with students who received conventional learning. The result of right side posttest hypothesis test showed $-1,68<2,67>1,68$ (-t table $\left.<t_{\text {test }}>t_{\text {table }}\right)$, then $H_{0}$ is refused and $H_{a}$ is accepted. It shows that the critical thinking skills between students who received SAVI learning approach is higher than students who received conventional learning. It shows that SAVI learning approach can improve student's critical thinking skills on social science subjects.
\end{abstract}

Keywords: critical thinking, social science subjects, SAVI approach

\section{Pendahuluan}

Pendidikan mempunyai pengaruh besar dalam kehidupan setiap manusia. Beragam potensi individu dalam aspek fisik, emosional, sosial, intelektual bahkan spiritual dapat dikembangkan dengan maksimal melalui pendidikan. Perbaikan sumber daya manusia juga tidak terlepas dari peranan penting pendidikan. Melalui berbagai jalur pendidikan formal, informal, dan nonformal yang telah diselenggarakan pemerintah sebagai salah satu upaya untuk memenuhi kebutuhan dalam bidang pendidikan. Salah satu pendidikan formal terpenting yaitu pendidikan dasar yang menjadi landasan untuk menuju jenjang pendidikan yang lebih tinggi. 
Kurikulum pendidikan dasar saat ini telah berubah menjadi Kurikulum 2013 dari yang semula Kurikulum Tingkat Satuan Pendidikan (KTSP). Terdapat beberapa perbedaan antara KTSP dengan K13, salah satunya yakni dalam proses kegiatan belajar mengajar. Kegiatan pembelajaran dalam KTSP masih dilakukan secara terpisah antarmata pelajaran, sedangkan pembelajaran dalam K13 telah berbasis tematik. Mata pelajaran Ilmu Pengetahuan Sosial (IPS) menjadi satu dari sekian banyak mata pelajaran yang diintegrasikan ke dalam tema.

Pada jenjang Pendidikan dasar, mata pelajaran IPS adalah disiplin ilmu sosial yang merupakan penggabungan dari bermacam cabang ilmu yang mempelajari masalahmasalah sosial di antaranya sejarah, sosiologi, antropologi, dan geografi (Jamaludin, 2017:2). Pembelajaran IPS meminta peserta didik untuk mengaitkan berbagai fakta, gagasan, dan peristiwa sehingga peserta didik mampu untuk menarik simpulan dari materi yang telah dipelajari. Peserta didik diajak untuk berpikir kritis dalam menyikapi masalah sosial yang terjadi di sekitarnya.

Ennis (Susanto, 2016:121) berpendapat berpikir kritis memiliki arti sebuah jalan berpikir dengan maksud untuk menciptakan simpulan yang logis tentang gagasan atau ide yang dipercaya. Berpikir kritis berarti kemampuan individu untuk menggunakan logikanya. Melalui kemampuan berpikir kritis, peserta didik dapat lebih mudah untuk menguasai konsep, peka akan masalah yang terjadi sehingga mampu menyelesaikan masalah serta mengaplikasikan konsep yang dimiliki dalam situasi berbeda. Namun kenyataan di lapangan, kebiasaan berpikir kritis belum ditradisikan di sekolah-sekolah, contohnya sekolah cenderung lebih sering memberikan jawaban yang benar daripada mendorong peserta didik untuk menemukan ide-ide baru atau memikirkan ulang kesimpulan-kesimpulan yang telah ada (Khoerunnisa, 2018:249).

Kondisi tersebut terjadi pula pada peserta didik kelas V SD Negeri Bojonegara 1, Kecamatan Bojonegara, Kabupaten Serang, Provinsi Banten. Berdasarkan hasil wawancara pra penelitian yang telah peneliti lakukan dengan guru kelas VA, di kelas tersebut terdapat beberapa permasalahan yang terjadi pada proses pembelajaran IPS, di antaranya guru hanya sesekali mengajar menggunakan pendekatan pembelajaran. Guru lebih sering mengajar seperti biasa yaitu dengan hanya menjelaskan materi melalui proses ceramah, tanya jawab, dan mengerjakan soal. Soal yang disusun oleh guru pun belum mampu untuk membuat kemampuan berpikir kritis peserta didik berkembang. Hal ini dikarenakan soal yang disusun, menurut dimensi kognitif Bloom hanya berada pada bagian dimensi pengetahuan (C1) dan pemahaman (C2). Sedangkan, kemampuan berpikir kritis menempati bagian dimensi aplikasi (C3), analisis (C4), dan evaluasi (C5) menurut dimensi kognitif Bloom.

Peran guru sangat diperlukan untuk membuat kemampuan berpikir kritis peserta didik berkembang. Hal yang dapat dilakukan oleh guru yaitu dengan penerapan pendekatan pembelajaran dengan memasukkan indikator-indikator kemampuan berpikir kritis ke dalam materi pembelajaran, serta pembelajaran yang bersifat kontekstual. Salah satu alternatif yang guru dapat terapkan untuk membuat kemampuan berpikir kritis peserta didik meningkat pada pembelajaran IPS yaitu dengan penerapan pendekatan pembelajaran SAVI (Somatis, Auditori, Visual, Intelektual).

Tuntutan supaya peserta didik aktif, kreatif, inovatif, dengan menggunakan seluruh alat indra dalam melakukan pembelajaran merupakan salah satu ciri khas dari pendekatan SAVI. Pendekatan SAVI memiliki empat unsur yaitu: Somatis (S), yaitu belajar melalui keterlibatan fisik; Auditori (A), yaitu belajar melalui kegiatan mendengarkan dan berbicara; Visual (V), yaitu belajar melalui pengamatan; Intelektual (I), yaitu belajar melalui kegiatan memecahkan masalah. Apabila 
keempat unsur SAVI diaplikasikan selama proses pembelajaran berlangsung, maka kegiatan belajar akan maksimal. Pendekatan SAVI dengan keempat unsur tersebut dapat memberikan ruang bagi peserta didik untuk mengasah dan mengembangkan kemampuan berpikir kritis (Fitriyani, 2015:4).

Hasil penelitian sebelumnya yang mendukung penerapan pendekatan SAVI untuk meningkatkan kemampuan berpikir kritis peserta didik adalah hasil penelitian Fitriyani, Ign. I Wy. Suwatra, dan Nym. Kusmariyatni (2015) dan hasil penelitian Nurmalia, Hana Silvana, dan Didi Supriadie (2017) bahwa terdapat perbedaan kemampuan berpikir kritis yang signifikan antara peserta didik yang mengikuti pembelajaran dengan pendekatan pembelajaran SAVI dan peserta didik yang mengikuti pembelajaran dengan pendekatan pembelajaran konvensional pada mata pelajaran IPA. Penggunaaan pendekatan SAVI (Somatis, Auditori, Visual, Intelektual) dalam pembelajaran IPS didukung dari hasil penelitian Aerwin Fauziah (2016) dan hasil penelitian Eka Nofri Ari Yanto (2017) yang menunjukkan bahwa implementasi pendekatan SAVI dapat meningkatkan aktivitas dan hasil belajar peserta didik pada mata pelajaran IPA dan IPS.

Atas dasar penjelasan di atas, peneliti mengangkat judul "Penerapan Pendekatan Pembelajaran SAVI (Somatis, Auditori, Visual, Intelektual) terhadap Kemampuan Berpikir Kritis Peserta didik pada Materi IPS di Kelas V SD”.

\section{Metode}

Metode penelitian memiliki pengertian proses ilmiah dengan maksud mendapatkan informasi berupa data guna tujuan dan manfaat tertentu (Sugiyono, 2014:2). Peneliti menggunakan metode eksperimen semu (Quasi Experimental) dengan desain penelitian Nonequivalent Control Group Design, yaitu dengan dua kelompok yang tidak dipilih secara acak, yaitu kelompok kontrol dan kelompok eksperimen.

Sampel pada penelitian ini adalah kelas VA sebagai kelompok eksperimen dengan 31 peserta didik yang diberikan perlakuan berupa kegiatan belajar dengan menggunakan pendekatan SAVI (Somatis, Auditori, Visual, Intelektual). Sampel berikutnya adalah kelas VB sebagai kelompok kontrol dengan 21 peserta didik dengan pembelajaran yang diserahkan kepada guru kelas. Teknik Non Probability Sampling yang digunakan dalam penelitian ini merupakan teknik pengambilan sampel yang tidak memberi kesempatan yang sama bagi setiap anggota populasi untuk dipilih menjadi sampel (Sugiyono, 2014:84). Teknik sampling yang dilakukan pada penelitian ini merupakan pengambilan sampel secara sampel bertujuan atau sampling purposive, yaitu teknik dalam menentukan sampel berdasarkan pertimbangan tertentu (Sugiyono, 2014:85). Pertimbangan dalam penelitian ini berkenaan dengan kemampuan akademik peserta didik. Pada materi IPS, kelas VB memperoleh nilai rerata sebesar 72,42. Nilai tersebut lebih tinggi daripada kelas VA yang memperoleh nilai rerata sebesar 61,50. Atas dasar nilai rerata tersebut, maka peneliti menjadikan kelas VB sebagai kelas kontrol dan kelas VA sebagai kelas eksperimen.

Instrumen penelitian untuk mengukur kemampuan berpikir kritis peserta didik dalam penelitian ini menggunakan tes objektif berupa 10 soal uraian singkat. 10 soal uraian singkat yang menjadi instrumen dalam penelitian ini disusun sesuai dengan indikator-indikator berpikir kritis menurut Ennis (Susanto, 2016:125). Berikut kisikisi soal kemampuan berpikir kritis yang dapat dilihat pada tabel 1 . 
Tabel 1. Kisi-kisi Tes Kemampuan Berpikir Kritis

\begin{tabular}{|c|c|c|c|c|}
\hline $\begin{array}{c}\text { Indikator } \\
\text { Berpikir Kritis }\end{array}$ & $\begin{array}{l}\text { Sub Indikator } \\
\text { Berpikir Kritis }\end{array}$ & Indikator Soal & $\begin{array}{c}\text { Ranah } \\
\text { Kognitif }\end{array}$ & $\begin{array}{l}\text { No } \\
\text { Soal }\end{array}$ \\
\hline \multirow[t]{3}{*}{$\begin{array}{c}\text { Memberikan } \\
\text { penjelasan } \\
\text { sederhana }\end{array}$} & $\begin{array}{c}\text { Memfokuskan } \\
\text { pertanyaan }\end{array}$ & $\begin{array}{c}\text { Peserta didik } \\
\text { mampu } \\
\text { menentukan } \\
\text { perlunya manusia } \\
\text { saling berinteraksi }\end{array}$ & C3 & 1 \\
\hline & $\begin{array}{l}\text { Menganalisis } \\
\text { argumen }\end{array}$ & $\begin{array}{c}\text { Peserta didik } \\
\text { mampu membangun } \\
\text { definisi tentang } \\
\text { interaksi sosial dan } \\
\text { tujuan dari } \\
\text { interaksi sosial }\end{array}$ & C3 & 2 \\
\hline & $\begin{array}{c}\text { Bertanya dan } \\
\text { menjawab } \\
\text { pertanyaan yang } \\
\text { menantang }\end{array}$ & $\begin{array}{c}\text { Peserta didik } \\
\text { mampu } \\
\text { mengklasifikasikan } \\
\text { contoh dari } \\
\text { interaksi sosial } \\
\text { antar individu, } \\
\text { individu dengan } \\
\text { kelompok, kelompok } \\
\text { dengan kelompok }\end{array}$ & C3 & 3 \\
\hline
\end{tabular}

\begin{tabular}{|c|c|c|c|c|}
\hline $\begin{array}{c}\text { Membangun } \\
\text { kecakapan dasar }\end{array}$ & $\begin{array}{l}\text { Mengobservasi dan } \\
\text { mempertimbangkan } \\
\text { laporan observasi }\end{array}$ & $\begin{array}{c}\text { Peserta didik } \\
\text { mampu } \\
\text { menganalisis } \\
\text { interaksi manusia } \\
\text { yang terjadi di } \\
\text { lingkungan sosial } \\
\text { dan lingkungan } \\
\text { alam }\end{array}$ & $\mathrm{C} 4$ & 10 \\
\hline \multirow[t]{2}{*}{ Menyimpulkan } & $\begin{array}{c}\text { Mendeduksi dan } \\
\text { mempertimbangkan } \\
\text { hasil deduksi }\end{array}$ & $\begin{array}{c}\text { Peserta didik } \\
\text { mampu menegaskan } \\
\text { alasan setelah } \\
\text { memberikan sebuah } \\
\text { pilihan }\end{array}$ & $\mathrm{C} 4$ & 5 \\
\hline & $\begin{array}{l}\text { Menginduksi dan } \\
\text { mempertimbangkan } \\
\text { hasil induksi }\end{array}$ & $\begin{array}{l}\text { Peserta didik } \\
\text { mampu membuat } \\
\text { garis besar atau } \\
\text { simpulan yang } \\
\text { dapat menjelaskan } \\
\text { suatu peristiwa }\end{array}$ & $\mathrm{C} 4$ & 9 \\
\hline \multirow[t]{2}{*}{$\begin{array}{c}\text { Memberikan } \\
\text { penjelasan lanjut }\end{array}$} & $\begin{array}{c}\text { Mendefinisikan } \\
\text { istilah dan } \\
\text { mempertimbangkan } \\
\text { suatu definisi }\end{array}$ & $\begin{array}{c}\text { Peserta didik } \\
\text { mampu membangun } \\
\text { definisi tentang } \\
\text { interaksi manusia } \\
\text { dengan lingkungan } \\
\text { alam sekitarnya dan } \\
\text { tujuan dari } \\
\text { interaksi tersebut }\end{array}$ & C3 & 6 \\
\hline & $\begin{array}{l}\text { Mengidentifikasi } \\
\text { asumsi-asumsi }\end{array}$ & $\begin{array}{c}\text { Peserta didik } \\
\text { mampu } \\
\text { menentukan contoh } \\
\text { bentuk interaksi } \\
\text { manusia dengan } \\
\text { lingkungan alam }\end{array}$ & C3 & 7 \\
\hline $\begin{array}{l}\text { Mengatur } \\
\text { strategi dan } \\
\text { taktik }\end{array}$ & $\begin{array}{l}\text { Menentukan suatu } \\
\text { tindakan }\end{array}$ & $\begin{array}{l}\text { Peserta didik } \\
\text { mampu } \\
\text { menentukan suatu } \\
\text { tindakan sebagai } \\
\text { makhluk sosial }\end{array}$ & C3 & 4 \\
\hline
\end{tabular}




\begin{tabular}{|c|c|c|c|}
\hline & $\begin{array}{l}\text { berdasarkan } \\
\text { gambar }\end{array}$ & & \\
\hline $\begin{array}{c}\text { Berinteraksi dengan } \\
\text { orang lain }\end{array}$ & $\begin{array}{c}\text { Peserta didik } \\
\text { mampu } \\
\text { menyelesaikan } \\
\text { masalah tentang } \\
\text { interaksi manusia } \\
\text { dengan lingkungan } \\
\text { alam sekitarnya }\end{array}$ & $\mathrm{C} 4$ & 8 \\
\hline
\end{tabular}

Lembar tes diuji cobakan pada peserta didik SD Negeri 1 Bojonegara kelas VI A dan VI B yang telah mempelajari materi yang dijadikan materi penelitian. Setelah uji coba, lembar tes tersebut diuji validitas, reliabilitas, tingkat kesukaran, dan daya pembeda soal. Pengujian instrumen tersebut yang dalam perhitungannya dibantu oleh Microsoft Office Excel 2019 didapatkan hasil bahwa 10 butir soal memiliki tingkat validitas dan reliabilitas yang tinggi, taraf kesukaran sedang, dan daya pembeda yang baik. Berdasarkan hasil pengujian instrumen tersebut, maka diputuskan bahwa 10 butir soal dipakai dalam penelitian ini untuk mengukur kemampuan berpikir kritis peserta didik.

Teknik pengumpulan data dalam penelitian ini dilakukan dengan tes dan nontes. Tujuan dilakukannya tes untuk mengukur aspek kognitif peserta didik. Tes terdiri dari pretest dan posttest dikarenakan peneliti menggunakan desain quasi experimental dengan bentuk nonequivalent control group design yang hampir sama dengan desain true experimental dengan bentuk pretest-posttest control grup design (Sugiyono, 2014:79). Pretest (tes awal) digunakan untuk mengetahui kemampuan berpikir kritis peserta didik pada keadaan awal sebelum diberikan perlakuan. Sedangkan posttest (tes akhir) digunakan untuk mengetahui kemampuan berpikir kritis peserta didik pada keadaan akhir setelah diberi perlakuan. Hasil posttest peneliti gunakan untuk mencari tahu apakah terdapat perbedaan kemampuan berpikir kritis antara peserta didik kelas eksperimen dan kelas kontrol. Apabila hasil posttest lebih baik dibandingkan hasil pretest, maka dapat diputuskan bahwa perlakuan yang diberikan terlaksana dengan efektif dan berhasil (Arikunto, 2012:67).

Naskah pretest dan posttest untuk pengukuran kemampuan berpikir kritis dalam penelitian ini menggunakan tes objektif berupa 10 soal uraian singkat. Naskah posttest disusun serupa dengan naskah pretest. Sedangkan instrumen nontes yang dipakai dalam penelitian ini berupa wawancara bebas terpimpin, observasi non partisipasi (nonparticipant observation), dan dokumentasi. Sebelum melakukan analisis data, terlebih dahulu dilakukan uji prasyarat analisis data berupa uji normalitas dan uji homogenitas. Tujuan dilakukannya uji normalitas yaitu untuk memperlihatkan apakah sampel diambil dari populasi yang berdistribusi normal atau berdistribusi tidak normal (Riduwan, 2010:188). Uji statistik untuk menguji normalitas menggunakan uji chi kuardrat $\left(\mathrm{X}^{2}\right)$ dengan taraf signifikan $\alpha=0,05$ serta $\mathrm{dk}=\mathrm{k}-1$ (k adalah jumlah kelas interval). Setelah didapatkan hasil perhitungan $\mathrm{X}^{2}$, tahap selanjutnya adalah membandingkan harga $X^{2}$ hitung dengan $X^{2}$ tabel dengan kriteria berikut.

Jika $X^{2}$ hitung $\leq X^{2}$ tabel maka data memiliki distribusi normal

Jika $\mathrm{X}^{2}$ hitung $>\mathrm{X}^{2}$ tabel maka data memiliki distribusi tidak normal

Apabila data telah diketahui berdistribusi normal, maka langkah selanjutnya adalah melakukan uji homogenitas. Tujuan dilakukannya uji homogenitas yaitu untuk memperlihatkan apakah dua kelompok sampel diambil dari populasi yang memiliki variasi yang sama (Riduwan, 2010:186). Uji homogenitas pada penelitian ini menggunakan uji $\mathrm{F}$ dengan perbandingan $\mathrm{F}_{\text {hitung }}$ dengan $\mathrm{F}_{\text {tabel}}$, dengan ketentuan taraf signifikansi $\alpha=0,05$. Berikut kriteria dalam uji $\mathrm{F}$. 
$\mathrm{F}_{\text {hitung }} \leq \mathrm{F}_{\text {tabel, }}$, maka varian homogen

$\mathrm{F}_{\text {hitung }}>\mathrm{F}_{\text {tabel}}$, maka varian tidak homogen

Peneliti menggunakan teknik analisis data berupa statistik deskriptif dan statistik inferensial (uji t). Teknik pengujian hipotesis yang digunakan antara lain uji 2 pihak (perbedaan dua rata-rata posttest) dan uji pihak kanan posttest menggunakan uji t dengan rumus polled varians dengan ketentuan $\alpha=0,05$.

\section{Hasil}

Penelitian ini dilaksanakan di Kelas V SD Negeri 1 Bojonegara, Kabupaten Serang, Provinsi Banten, pada semester ganjil. Kelas VA yang berjumlah 31 orang sebagai kelas eksperimen, sedangkan kelas VB yang berjumlah 21 orang sebagai kelas kontrol. Penelitian ini dilaksanakan selama 4 pertemuan, 2 pertemuan di kelas kontrol dan 2 pertemuan di kelas eksperimen. Pokok bahasan Ilmu Pengetahuan Sosial (IPS) yang diajarkan pada penelitian ini yaitu tentang "Interaksi Sosial dan Interaksi dengan Lingkungan Alam Sekitar".

Sebelum diuji hipotesis, data pretest dan posttest terlebih dahulu diolah untuk dicari nilai rata-rata, kemudian dicari nilai tertinggi, nilai terendah, simpangan baku, dan varian. Berikut hasil perhitungan pretest dan posttest kemampuan berpikir kritis peserta didik kelas kontrol dan kelas eksperimen yang dapat dilihat pada tabel 2 .

Tabel 2. Statistik Deskriptif Hasil Pretest dan Posttest Kemampuan Berpikir Kritis Peserta Didik

\begin{tabular}{ccccc}
\hline \multirow{2}{*}{ Statistik } & \multicolumn{2}{c}{ Kelas Eksperimen } & \multicolumn{2}{c}{ Kelas Kontrol } \\
\cline { 2 - 5 } & Pretest & Posttest & Pretest & Posttest \\
\hline Banyak Siswa & 31 & 31 & 21 & 21 \\
\hline Nilai terendah & 0 & 24 & 8 & 20 \\
\hline Nilai Tertinggi & 64 & 100 & 72 & 84 \\
\hline Rata-rata & 27 & 67,74 & 36,29 & 52 \\
\hline Simpangan Baku & 15,56 & 22,35 & 17,51 & 18,38 \\
\hline Varian & 242 & 499,73 & 306,61 & 338 \\
\hline
\end{tabular}

Berdasarkan tabel 2 di atas dapat disimpulkan pada diagram 1 bahwa terdapat perbedaan pada nilai rata-rata kemampuan berpikir kritis kedua kelas.

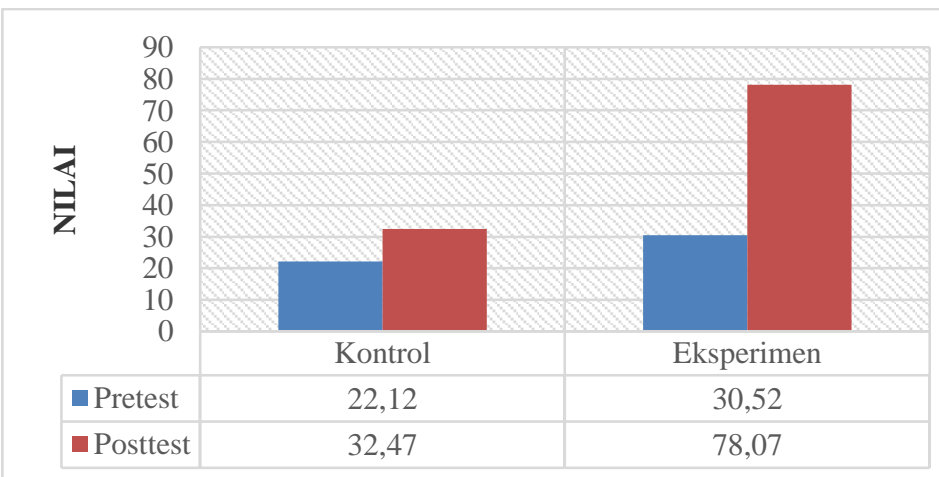

Diagram 1. Nilai Rata-Rata Pretest dan Posttest Kemampuan Berpikir Kritis Peserta Didik Kelas Kontrol dan Kelas Eksperimen

Untuk statistik inferensial, peneliti melakukan uji prasyarat analisis data berupa uji normalitas dan uji homogenitas. Tujuan dilakukannya uji normalitas yaitu untuk memperlihatkan apakah sampel diambil dari populasi yang berdistribusi normal atau berdistribusi tidak normal. Uji normalitas dalam penelitian ini menggunakan uji chi kuardrat $\left(x^{2}\right)$ dengan taraf signifikan $\mathrm{a}=0,05$ serta $\mathrm{dk}=\mathrm{k}-1$ (k adalah jumlah 
kelas interval). Berikut adalah hasil pengujian normalitas data pretest dan posttest kelas kontrol dan kelas eksperimen yang dapat dilihat pada tabel 3.

Tabel 3. Hasil Uji Normalitas Pretest dan Posttest Kelas Kontrol dan Eksperimen

\begin{tabular}{ccccc}
\hline Test & \multicolumn{2}{c}{ Pretest } & \multicolumn{2}{c}{ Posttest } \\
\hline Kelas & Kontrol & Eksperimen & Kontrol & Eksperimen \\
\hline Dk & 4 & 5 & 4 & 5 \\
\hline $\boldsymbol{x}^{2}$ hitung & 3,35 & 9,47 & 3,06 & 8,73 \\
\hline $\boldsymbol{x}^{2}$ tabel & 9,49 & 11,07 & 9,49 & 11,07 \\
\hline Keputusan & Normal & Normal & Normal & Normal \\
\hline
\end{tabular}

Pengujian homogenitas dilakukan setelah data diketahui berdistribusi normal. Tujuan dilakukannya uji homogenitas yaitu untuk memperlihatkan apakah dua kelompok sampel diambil dari populasi yang memiliki variansi yang sama. Uji homogenitas dimaksudkan untuk memperlihatkan bahwa dua atau lebih kelompok data sampel berasal dari populasi yang memiliki varians yang sama. Uji homogenitas pada penelitian ini menggunakan uji $\mathrm{F}$ dengan perbandingan $\mathrm{F}_{\text {hitung }}$ dengan $\mathrm{F}_{\text {tabel, }}$, dengan ketentuan taraf signifikansi $\alpha=0,05$, dk pembilang $=\mathrm{n}_{1}-1=$ $21-1=20$, dk penyebut $=\mathrm{n}_{2}-1=31-1=30$, maka $\mathrm{F}_{\text {tabel }}=1,93$ (diperoleh dengan menggunakan tabel distribusi F). Berikut adalah hasil pengujian homogenitas pretest dan posttest kelas kontrol dan kelas eksperimen yang dapat dilihat pada tabel 4.

Tabel 4. Hasil Uji Homogenitas Pretest dan Posttest Kelas Kontrol dan Eksperimen

\begin{tabular}{ccccc}
\hline Kelas & Kontrol & Eksperimen & Kontrol & Eksperimen \\
\hline Varian & 306,61 & 242 & 338 & 499,73 \\
\hline F $_{\text {hitung }}$ & 1,27 & & 1,48 \\
\hline F tabel $_{\text {Keputusan }}$ & \multicolumn{2}{c}{1,93} & & 2,04 \\
\hline Homogen & Homogen
\end{tabular}

Hasil pengujian normalitas dan homogenitas data pretest dan posttest kelas kontrol dan kelas eksperimen yaitu didapatkan data yang memiliki distribusi normal dan bersifat homogen. Maka selanjutnya dilakukan uji hipotesis. Untuk menguji hipotesis 1 digunakan uji perbedaan dua rata-rata menggunakan uji t dengan rumus polled varians dengan ketentuan $\alpha=0,05$.

Berdasarkan hasil uji t perbedaan dua rata-rata nilai posttest, didapatkan hasil thitung $=2,67$ dan $t_{\text {tabel }}=2,01$ (diperoleh dengan menggunakan tabel distribusi $\mathrm{T}$ ). Hal tersebut menunjukkan bahwa thitung lebih besar dari tabel, maka $\mathrm{H}_{0}$ ditolak dan $\mathrm{H}_{\mathrm{a}}$ diterima, - $t_{\text {tabel }}<t_{\text {hitung }}>t_{\text {tabel }}$ atau $-2,01<2,67>2,01$. Maka dapat disimpulkan bahwa terdapat perbedaan kemampuan berpikir kritis antara peserta didik yang mendapat perlakuan pendekatan pembelajaran SAVI (Somatis, Auditori, Visual, dan Intelektual) dengan peserta didik yang mendapat perlakuan pembelajaran konvensional pada materi IPS pada tes akhir. Sehingga secara statistik dapat dibuktikan bahwa kelas kontrol dan kelas eksperimen memiliki kemampuan akhir yang berbeda.

Setelah dilakukan uji perbedaan dua rata-rata, selanjutkan dilakukan uji satu pihak untuk menguji hipotesis 2 menggunakan uji t dengan rumus polled varians dengan ketentuan $\alpha=0,05$. Berdasarkan hasil uji t pihak kanan posttest, didapatkan hasil $t_{\text {hitung }}=2,67$ dan $t_{\text {tabel }}=1,68$ (diperoleh dengan menggunakan tabel distribusi $\mathrm{T}$ ). Hal tersebut menunjukkan bahwa thitung lebih besar dari tabel, maka $\mathrm{H}_{0}$ ditolak dan $\mathrm{H}_{a}$ diterima, - $t_{\text {tabel }}<t_{\text {hitung }}>t_{\text {tabel }}$ atau $-1,68<2,67>1,68$. Sehingga dapat disimpulkan bahwa kemampuan berpikir kritis peserta didik yang mendapat perlakuan pendekatan pembelajaran SAVI (Somatis, Auditori, Visual, dan Intelektual) lebih tinggi daripada peserta didik yang mendapat perlakuan pembelajaran konvensional pada materi IPS. 


\section{Pembahasan}

Berdasarkan pada hasil penelitian yang menunjukkan bahwa peserta didik kelas eksperimen memiliki kemampuan berpikir kritis lebih tinggi daripada kelas kontrol dikarenakan penerapan pendekatan pembelajaran SAVI. Peneliti membuat seluruh tubuh dan pikiran setiap peserta didik terlibat secara penuh selama proses belajar melalui pemanfaatan indra sebanyak mungkin.

Meier (2003:91) menyatakan bahwa meminta peserta didik untuk berdiri dan bergerak kesana-kesini tidak akan terjadi peningkatan secara otomatis dalam pembelajaran. Penggunaan alat indra akan memiliki pengaruh besar pada pembelajaran jika pembelajaran berisi kegiatan yang dapat menggabungkan gerakan fisik dengan aktivitas intelektual peserta didik. Pendekatan SAVI merupakan pendekatan pembelajaran yang melibatkan seluruh anggota tubuh mulai dari gerakan tubuh, kemampuan mendengar, kemampuan menggambarkan, dan kemampuan cendekia atau berhubungan dengan perumusan, perenungan, serta pengintegrasian dengan pemfungsian pikiran secara baik dan benar (Haerudin, 2013). Melalui kegiatan-kegiatan yang terdapat dalam pembelajaran dengan penerapan pendekatan pembelajaran SAVI, secara tidak langsung kemampuan berpikir kritis peserta didik dilatih dan dikembangkan.

Pendekatan SAVI memiliki empat tahapan dalam kegiatan pembelajaran, antara lain tahap persiapan, tahap penyampaian, tahap pelatihan, dan tahap penyampaian hasil (Shoimin, 2014:178). Keempat tahapan tersebut ditujukan agar kemampuan berpikir kritis peserta didik di kelas eksperimen dapat meningkat.

Tahap Persiapan; pada tahap persiapan ini, indikator berpikir kritis yang dikembangkan adalah indikator memfokuskan pertanyaan dan indikator mengidentifikasi asumsi. Tahap ini berada di kegiatan pendahuluan dalam langkahlangkah pembelajaran yang dilakukan peneliti di kelas eksperimen.

Untuk meningkatkan kedua indikator kemampuan berpikir kritis peserta didik tersebut, peneliti mengkondisikan agar peserta didik siap belajar dengan memberitahukan tema, materi, dan tujuan pembelajaran dan membagi peserta didik ke dalam 6 kelompok heterogen (unsur somatis). Selanjutnya, peneliti memotivasi peserta didik agar proses pembelajaran berlangsung aktif dan menyenangkan. Kegiatan pada tahap persiapan tersebut sesuai dengan yang dikemukakan Meier (2003:106) yaitu pada tahap persiapan, guru membangkitkan minat belajar peserta didik, guru memberikan perasaan positif mengenai pengalaman belajar yang akan datang dan menempatkan peserta didik dalam situasi optimal untuk belajar.

Tahap Penyampaian; pada tahap ini, indikator berpikir kritis yang dikembangkan adalah indikator menganalisis argumen, indikator bertanya dan menjawab tentang suatu penjelasan atau tantangan, serta indikator berinteraksi dengan orang lain. Tahap ini berada di kegiatan inti dalam langkah-langkah pembelajaran yang dilakukan peneliti di kelas eksperimen.

Tahap penyampaian menjadi waktu yang tepat untuk mempertemukan peserta didik dengan materi belajar yang akan menjadi awal proses belajar yang positif serta menarik (Meier, 2003:132). Peneliti menyajikan materi interaksi sosial dan interaksi dengan lingkungan alam sekitar dengan menggunakan media gambar. Peserta didik menyimak penjelasan peneliti dan mencatat bagian penting dari materi yang disampaikan. Unsur SAVI yang digunakan adalah visual, auditori, dan intelektual.

Pemilihan mata pelajaran IPS dan materi interaksi manusia dengan lingkungan sosial dan lingkungan alam sekitarnya sesuai dengan hakikat IPS di sekolah dasar 
yaitu sebagai media pelatihan agar peserta didik mendapat pengetahuan dan keterampilan dasar sedini mungkin sebagai warga negara. Bukan hanya pada pemberian ilmu pengetahuan semata, IPS juga memiliki orientasi untuk mengembangkan keterampilan berpikir kritis, kecakapan dasar dan sikap peserta didik berdasarkan kehidupan keseharian masyarakat serta pemenuhan kebutuhan di masyarakat bagi kehidupan sosial peserta didik (Susanto, 2016:138).

Untuk meningkatkan ketiga indikator kemampuan berpikir kritis peserta didik, peneliti dan peserta didik melakukan diskusi dan tanya jawab mengenai materi yang sedang dipelajari sehingga terjadi interaksi yang baik dalam pembelajaran. Hal tersebut sesuai dengan yang dikatakan Meier (2003:133) bahwa dalam tahap penyampaian, keterlibatan aktif peserta didik sangat diperlukan dalam menciptakan pengetahuan di setiap prosesnya, bukan hanya keterlibatan dari fasilitator saja.

Kendala yang peneliti temukan dalam tahap penyampaian yaitu peserta didik yang memiliki kemampuan lemah akan kesulitan untuk memahami materi baru. Selain itu, saat kegiatan diskusi masih banyak peserta didik yang kesulitan mengemukakan gagasan bahkan untuk sekedar menjawab sebuah pertanyaan yang diajukan. Hal ini sesuai dengan yang dikemukakan Shoimin (2014:183) bahwa salah satu kekurangan pendekatan pembelajaran SAVI di antaranya yaitu peserta didik dengan kemampuan lemah akan membutuhkan waktu cukup lama karena mereka terbiasa diberikan materi atau informasi terlebih dahulu, sehingga kesulitan menemukan jawaban ataupun gagasannya sendiri.

Tahap Pelatihan; pada tahap ini, indikator berpikir kritis yang dikembangkan adalah indikator menentukan tindakan, indikator mendefinisikan istilah dan pertimbangan definisi dalam tiga dimensi, indikator berinteraksi dengan orang lain, serta indikator mengamati dan mempertimbangkan suatu laporan hasil observasi. Tahap ini berada di kegiatan inti dalam langkah-langkah pembelajaran yang dilakukan peneliti di kelas eksperimen.

Untuk meningkatkan keempat indikator kemampuan berpikir kritis, peserta didik ditugaskan untuk melakukan pengamatan interaksi manusia di lingkungan sekitar sekolah melalui penugasan LKPD. Setelah mengamati, setiap kelompok melakukan diskusi untuk menjawab beberapa pertanyaan yang terdapat dalam LKPD. Hal ini sesuai dengan yang dikatakan Meier (2003:149) dalam salah satu Gudang gagasan untuk tahap pelatihan yaitu pelatihan memecahkan masalah. Kelompokkan para pembelajar dalam kelompok kecil dan beri mereka satu atau serangkaian masalah yang harus mereka pecahkan dalam jangka waktu tertentu. Masalah tersebut harus dari dunia nyata yang dapat menguji pemahaman dan kemampuan mereka untuk menerapkan pengetahuan dan keterampilan yang baru saja mereka pelajari.

Dengan pembelajaran secara kontekstual tersebut, peserta didik akan mendapatkan kebermaknaan belajar sehingga tidak mudah lupa apa yang telah dikerjakan dan dialami. Hal tersebut sejalan dengan pendapat Shoimin (2014:183) bahwa kelebihan dari pendekatan pembelajaran SAVI di antaranya yaitu melatih peserta didik untuk terbiasa menggunakan kemampuan berpikirnya dan dapat mengemukakan pendapat serta berani menjelaskan jawabannya. Selain itu, peserta didik tidak cepat lupa tentang materi yang sedang dipelajari karena peserta didik membangun sendiri pengetahuannya.

Selanjutnya, peneliti mengajak peserta didik melakukan permainan "CEPAT TEPAT INTERAKSI". Setiap kelompok melakukan diskusi dalam mencari jawaban dari beberapa pertanyaan dan menggolongkan contoh interaksi dengan cepat dan tepat. Permainan tersebut bertujuan untuk meningkatkan kerjasama dan kemampuan berpikir kritis peserta didik dalam memecahkan masalah. Hal tersebut sejalan dengan pendapat Shoimin (2014:183) bahwa kelebihan dari pendekatan 
pembelajaran SAVI di antaranya yaitu memupuk kerja sama, karena peserta didik yang lebih pandai diharapkan dapat membantu peserta didik yang tidak terlalu pandai.

Kegiatan pada tahap pelatihan tersebut sesuai dengan yang dikemukakan Meier (2003:107), yaitu pada tahap ini, guru hendaknya membantu peserta didik dalam pengintegrasian serta penyerapan pengetahuan dan keterampilan baru melalui beragam cara, seperti simulasi dunia nyata; permainan dalam belajar; pelatihan aksi pembelajaran; aktivitas pemecahan masalah; pengajaran dan tinjauan kolaboratif; aktivitas praktis membangun keterampilan.

Tahap Penyampaian Hasil; indikator kemampuan berpikir kritis yang dikembangkan dalam tahap ini adalah indikator mendeduksi dan mempertimbangkan hasil deduksi serta indikator membuat dan menentukan nilai pertimbangan induksi. Tahap ini berada di kegiatan inti terakhir dan kegiatan penutup dalam langkah-langkah pembelajaran yang dilakukan peneliti di kelas eksperimen.

Untuk meningkatkan kedua indikator kemampuan berpikir kritis peserta didik, peneliti meminta setiap kelompok untuk memaparkan hasil diskusi kelompoknya di depan kelas melalui kegiatan presentasi. Peneliti juga meminta kelompok lain untuk memberi kritik dan saran terhadap hasil kerja kelompok temannya. Selanjutnya, peneliti bersama peserta didik membuat simpulan dari materi yang telah dipelajari. Hal ini sesuai dengan yang dikatakan Meier (2003:161) bahwa mengevaluasi dan meningkatkan program belajar dapat berupa evaluasi berdasar tim.

Pada kelas kontrol, pembelajaran menggunakan pendekatan konvensional yang didominasi dengan metode ceramah. Pembelajaran seperti itu cenderung membuat peserta didik secara fisik tidak aktif dalam jangka waktu lama. Guru berperan sebagai pengendali urutan materi dan informasi yang diterima peserta didik. Guru sebagai pemberi informasi sebanyak-banyaknya, kemudian peserta didik memindahkan ke buku catatan dilanjutkan dengan pemberian tugas. Hal ini berakibat pembelajaran menjadi tidak efektif.

\section{Simpulan}

Berdasarkan hasil penelitian dan pembahasan, diperoleh simpulan sebagai berikut: 1) Hasil uji hipotesis perbedaan rata-rata kemampuan berpikir kritis peserta didik melalui uji $\mathrm{t}$ dua pihak menunjukkan hasil perbandingan $-2,01<2,67>2,01$, sehingga $\mathrm{H}_{0}$ ditolak dan $\mathrm{H}_{a}$ diterima. Maka, diperoleh simpulan bahwa terdapat perbedaan kemampuan berpikir kritis antara peserta didik yang mendapat perlakuan pendekatan SAVI dengan peserta didik yang mendapat perlakuan pembelajaran konvensional pada materi IPS. Perbedaan kemampuan berpikir kritis ditunjukkan melalui rata-rata nilai posttest kelas eksperimen sebesar 78,07 sedangkan pada kelas kontrol sebesar 32,47,2) Kemampuan berpikir kritis peserta didik yang mendapat perlakuan pendekatan SAVI lebih tinggi daripada peserta didik yang mendapat perlakuan pembelajaran konvensional. Hal ini dibuktikan dari hasil perhitungan uji-t pihak kanan yang menunjukkan $-1,68<2,67>1,68$, sehingga Ho ditolak dan $\mathrm{H}_{\mathrm{a}}$ diterima. Jadi dapat disimpulkan bahwa kemampuan berpikir kritis peserta didik yang mendapat perlakuan pendekatan SAVI lebih tinggi daripada peserta didik yang mendapat perlakuan pembelajaran konvensional pada materi IPS. Hal ini juga ditunjukkan melalui rata-rata nilai posttest kelas eksperimen yang lebih tinggi yaitu 78,07 sedangkan rata-rata nilai posttest kelas kontrol yaitu 32,47 . 
Berdasarkan hasil penelitian, peneliti memberikan saran sebagai berikut: 1) Peserta didik diharapkan lebih aktif dan lebih memiliki keberanian untuk mengemukakan pendapatnya pada saat pembelajaran, 2) Pendekatan SAVI dapat dijadikan alternatif pendekatan pembelajaran yang digunakan oleh guru. Berdasarkan hasil penelitian yang telah dilakukan, terbukti bahwa pendekatan pembelajaran ini dapat membuat kemampuan berpikir kritis peserta didik meningkat. Oleh karena itu, guru hendaknya mencoba untuk menerapkan pendekatan SAVI dalam kegiatan pembelajaran di kelas, 3) Sekolah diharapkan dapat membuat kemampuan berpikir kritis peserta didiknya berkembang dalam setiap pembelajaran, terutama pembelajaran IPS. Selain itu, perlu adanya penelitian lebih lanjut untuk menemukan pendekatan-pendekatan pembelajaran yang dapat membuat kemampuan berpikir kritis peserta didik meningkat, 4) Bagi peneliti selanjutnya, penelitian ini diharapkan dapat menjadi bahan referensi dalam mengembangkan pendekatan SAVI pada variabel, jenjang, dan mata pelajaran lain selain mata pelajaran IPS.

\section{Referensi}

Arikunto. S., (2012). Dasar-Dasar Evaluasi Pendidikan Edisi 2. Jakarta: Bumi Aksara.

Fauziah. A. (2016). Perbedaan Hasil Belajar IPA Siswa Menggunakan Pendekatan Somatis, Auditori, Visual, Intelektual (SAVI) dengan Pendekatan Explicit Instruction pada Materi Peristiwa Alam Beserta Dampaknya (Penelitian Kuasi Eksperimen terhadap Siswa Kelas V SDN Keboncau III). Skripsi. Tidak Diterbitkan. Serang: Program Sarjana Universitas Sultan Ageng Tirtayasa.

Fitriyani. Ign. I Wy. Suwatra, Nym. Kusmariyatni. (2015). Pengaruh Model SAVI terhadap Kemampuan Berpikir Kritis Siswa dalam Mata Pelajaran IPA Kelas V SD. EJournal PGSD Universitas Pendidikan Ganesha, 3(1), 1-12.

Haerudin. (2013). Pengaruh Pendekatan SAVI Terhadap Kemampuan Komunikasi dan Penalaran Matematika Serta Kemandirian Belajar Siswa SMP. Infinity Journal, 2(2), 186-188.

Jamaludin. U., Reza Rachmatullah. (2017). Pembelajaran Pendidikan IPS (Teori, Konsep, dan Aplikasi Bagi Guru dan Mahasiswa). Bekasi: Nurani.

Khoerunnisa. S., (2018), Keefektifan Media Spotlight Book dengan Model SAVI terhadap Kemampuan Berpikir Kritis pada Mata Pelajaran IPS. Jurnal Ilmiah Pendidikan dan Pembelajaran (JIPP), 2(3), 248-257.

Meier., D. (2003), The Accelerated Learning Handbook: Panduan Kreatif dan Efektif Merancang Program Pendidikan dan Pelatihan (diterjemahkan oleh: Rahmani Astuti), Bandung: Kaifa.

Nurmalia. Hana Silvana. Didi Supriadie. (2017). Efektivitas Penerapan Model Pembelajaran Somatic, Auditory, Visualization, Intellectually (SAVI) terhadap Peningkatan Kemampuan Berpikir Kritis Siswa pada Mata Pelajaran IPA (Kuasi Eksperimen terhadap Siswa Kelas VII di SMP Negeri 9 Bandung). Edutcehnologia, 3(2), 122-132.

Riduwan. (2010), Dasar-Dasar Statistika Bandung, Jakarta: Alfabeta.

Shoimin., A. (2014), 68 Model Pembelajaran Inovatif dalam Kurikulum 2013, Yogyakarta: Ar-Ruzz Media.

Sugiyono. (2014). Metode Penelitian Kuantitatif Kualitatif dan R\&D, Bandung: Alfabeta.

Susanto., A. (2016). Teori Belajar dan Pembelajaran di Sekolah Dasar, Jakarta: Kencana Prenada Media Group.

Yanto., E., N., A. (2017). Penggunaan Model Pembelajaran SAVI untuk Meningkatkan Prestasi Belajar IPS pada Siswa Kelas V SD Al Husna Kota Madiun, Jurnal Kependidikan Dasar Islam Berbasis Sains, 2(2), 33-42. 